\title{
Factors Affecting Employee Performance \\ In Corona 19 Pandemic PT. Berlian Palugada Perkasa Cilegon- Banten
}

\author{
Suhartini \\ suhartini@unsera.ac.id \\ Serang Raya University
}

The pandemic period which lasted throughout 2020 gave its own meaning to a company, this study aims to determine the factors- factors affecting employee performance during the pandemic corona 19 at PT Berlian Palugada Perkasa Cilegon Banten. This study used a sample of 50 employees of PT. Berlian Palu Gada Cilegon, which is a saturated sample. The method is descriptive quantitative method and the analysis used includes reliability testing, validity testing, classical assumption tests, multiple linear regression analysis and hypothesis testing with the help of SPSS software version 25.0. Based on the results of the study, it shows that partially the work experience variable has a significant effect on employee performance by 4.005 with a significance of 0.000 , so partially the work ability variable has a significant effect on employee performance by 2.533 with a significance of 0.015 and together the work experience and work ability variables have a significant effect. on employee performance of 27.042 with a significance of 0.000 . However, management still needs to pay attention to indicators in work experience and ability, especially by providing training and development for employees so that the expected performance is in accordance with the organization's goals.

Keywords: employee performance, work experience, work ability 


\section{PRELIMINARY}

Throughout 2020 was a year full of tests for almost all companies in the world. Likewise in Indonesia, especially at the local Banten level, especially the private company, PT Berlian Palugada Perkasa, work hand in hand so that the company can survive the crisis that was directly affected by this pandemic. In general, the Company is currently still carrying out work activities, even though the work carried out has decreased significantly, the most important thing is to note that the company is very empathetic in not laying off employees throughout 2020, even though work activities are very limited.

The company, which was established for ten years based on Decree Number AHU-0002304.AH.01.01 of 2010, dated September 13, 2010, is still relatively young when viewed from the tenure of a company's activities, however, it shows good performance when looking at the work achieved. This company is engaged in construction, especially in the Civil, Mechanical \& Electrical fields, and renting heavy project equipment. Services carried out in the civil sector include road projects, bridges, flyovers, city drainage, dams, concreting, steel construction, land preparation and stripping. In the field of Mechanical and \& Electrical, services carried out are heating installation, air ventilation and air conditioning in buildings and their maintenance, water and gas piping in buildings and their maintenance, installation of elevators and escalators, electrical installations for buildings and factories including maintenance, telecommunication distribution networks. Heavy equipment projects for rent include bulldozers, excavators, dump trucks, tower cranes, scrapers, clemshells, draglines, concrete pavers and many more.

It is understood that every company puts performance as a measure in achieving its organizational goals, a company must also strive in such a way as to be able to encourage the realization of the vision, mission, goals and objectives that have been set. Company performance, of course, depends on the performance of its employees, if the employee's performance is good / high, it is certain that the company will be able to survive and even develop well. Of course, many factors will affect employee performance, including work experience variables and work ability variables. At PT Berlian Palugada Perkasa, it was identified that their work experience was still insignificant when compared to the year the company was founded and the number of types of businesses this company served. It can be seen in the indicator of "working period", the average employee works less than 5 years on average, Likewise the indicators of the level of "knowledge" and "mastery" are still below the expected level. Meanwhile, from the variable side of employee work ability PT Berlian Palugada Perkasa is not in optimal condition. This is shown by the indicator "technical training that has been followed is always appropriate in the field of work," and the indicator "technical training according to the needs of the field of work". From the independent variable, it is interesting to study how the influence of work experience on performance on the performance of employees of PT Berlian Palugada Perkasa. how is the influence of employee work ability on the performance of employees of PT Berlian Palugada Perkasa and how is the influence of work experience and ability on the performance of employees of PT Palugada Perkasa Cilegon during the corona 19 pandemic, 2020.

\section{RESULTS AND DISCUSSION}

In this study the authors used quantitative descriptive research with a sample size as many as 50 employees as a saturated sample. The data collection technique used 
a questionnaire that was filled in directly by the employees of PT Berlian Palugada Perkasa. Measurement of data for independent and dependent variables is measured using the Likert scale, namely the scale range which is the assessment ranking of the independent and dependent variables to measure a person's attitudes, opinions and perceptions about social symptoms.

Data Analysis Technique

Test Instruments

Validity Test

Validity of Work Experience

Table 1.1

Validity Test of Work Experience (X1)

\begin{tabular}{|c|c|c|c|}
\hline Item & $\begin{array}{c}\text { Rcoun } \\
\mathrm{t}\end{array}$ & $\begin{array}{c}\text { rtable } \mathrm{a}=0.05 ; \mathrm{n}= \\
50\end{array}$ & $\begin{array}{c}\text { Descriptio } \\
\mathrm{n}\end{array}$ \\
\hline $\mathrm{X}_{1.1}$ & 0.819 & 0.2787 & Valid \\
\hline $\mathrm{X}_{1.2}$ & 0,781 & 0.2787 & Valid \\
\hline $\mathrm{X}_{1.3}$ & 0.732 & 0.2787 & Invalid \\
\hline $\mathrm{X} 1.4$ & 0.695 & 0.2787 & Valid \\
\hline $\mathrm{X} 1.5$ & 0.743 & 0.2787 & Invalid \\
\hline $\mathrm{X} 1.6$ & 0.833 & 0.2787 & Valid \\
\hline
\end{tabular}

Data source: Processed data

From the table above, it can be stated, in the validity test of the employee work experience variable, that all statement items in the questionnaire show valid, as evidenced by $\mathrm{R}$ count $>$ from $\mathrm{R}$ table. So that data can be processed and research can be continued.

Job Ability Validity

Table 1.2

Job Ability Validity Test (X2)

\begin{tabular}{|c|c|c|c|}
\hline $\begin{array}{c}\text { Ite } \\
\mathrm{m}\end{array}$ & Rcount & $\begin{array}{c}\text { rtable } \mathrm{a}=0.05 ; \mathrm{n}= \\
50\end{array}$ & $\begin{array}{c}\text { Descriptio } \\
\mathrm{n}\end{array}$ \\
\hline $\mathrm{X}_{2.1}$ & 0.534 & 0.2787 & Valid \\
\hline $\mathrm{X}_{2.2}$ & 0.746 & 0.2787 & Valid \\
\hline $\mathrm{X}_{2.3}$ & 0.746 & 0.2787 & Valid \\
\hline $\mathrm{X}_{2.4}$ & 0.670 & 0.2787 & Valid \\
\hline $\mathrm{X} 2.5$ & 0,600 & 0.2787 & Valid \\
\hline
\end{tabular}

Source Data: Processed data 
From the table above it can be argued, in the variable validity test of employee work ability, that all statement items in the questionnaire show valid, as evidenced by $\mathrm{R}$ count $>$ from $\mathrm{R}$ table. So that data can be processed and research can be continued.

\section{Validity of Employee Performance}

Table 1.3

Validity Test of Employee Performance (Y)

\begin{tabular}{|c|c|c|c|}
\hline Item & Rcount & $\begin{array}{c}\text { rtable } \mathrm{\alpha}=0.05 ; \mathrm{n}= \\
50\end{array}$ & $\begin{array}{c}\text { Descriptio } \\
\mathrm{n}\end{array}$ \\
\hline $\mathrm{Y} .1$ & 0.822 & 0.2787 & Valid \\
\hline $\mathrm{Y} .2$ & 0.651 & 0.2787 & Valid \\
\hline Y.3 & 0.824 & 0.2787 & Valid \\
\hline Y.4 & 0.860 & 0.2787 & Valid \\
\hline Y.5 & 0.735 & 0.2787 & Valid \\
\hline Y.6, & 0.723 & 02787 & Valid \\
\hline
\end{tabular}

Data source: Processed data

From the table above it can be argued, in the validity test of employee work performance variables, that all statement items in the questionnaire show valid, as evidenced by $R$ count $>$ from $R$ table. So that data can be processed and research can be continued

\section{Reliability Test}

1.1 Work Experience Reliability

Table 1.4

Work Experience Reliability Test (X1)

\begin{tabular}{|c|r|}
\hline \multicolumn{2}{|c|}{ Reliability Statistics } \\
\hline Cronbach's Alpha & N of Items \\
\hline 0.840 & 6 \\
\hline
\end{tabular}

1.2 Workability Reliability

Table 1.5

Workability Reliability Test (X2)

\begin{tabular}{|c|r|}
\hline \multicolumn{2}{|c|}{ Reliability Statistics } \\
\hline Cronbach's Alpha & N of Items \\
\hline 0.669 & 5 \\
\hline
\end{tabular}




\subsection{Employee Performance ReliabilityEmployee}

Table 1.6

\section{Performance Reliability Test (Y)}

\begin{tabular}{|c|c|}
\hline \multicolumn{2}{|c|}{ Reliability Statistics } \\
\hline Cronbach's Alpha & N of Items \\
\hline 0.856 & 6 \\
\hline
\end{tabular}

Based on the reliability test table above which using Alpha Cronbach's method for the consistency level of work experience variables obtained an alpha value of 0.840 , the work ability variable obtained an alpha value of 0.669 and the Performance variable obtained an alpha value of 0.856 . This means that the Cronbach's alpha obtained $>\mathrm{r}$ table (more than) of 0.60 , it means that all statements contained in the questionnaire are declared reliable / consistent.

\section{Calcic Assumption Test}

Normality Test

Table 1.7 Kolmogorov-Smirnov

\begin{tabular}{|c|c|c|}
\hline \multicolumn{3}{|c|}{ One-Sample Kolmogorov-Smirnov TestTest } \\
\hline & & $\begin{array}{l}\text { Unstandardized } \\
\text { Residual }\end{array}$ \\
\hline \multicolumn{2}{|l|}{$\mathrm{N}$} & 50 \\
\hline \multirow[t]{2}{*}{ Normal Parameters ${ }^{\mathrm{a}, \mathrm{b}}$} & Mean & 0.0000000 \\
\hline & Std. Deviation & 1,96882149 \\
\hline \multirow{3}{*}{$\begin{array}{l}\text { Most Extreme } \\
\text { Differences }\end{array}$} & Absolute & 0.082 \\
\hline & Positive & 0.048 \\
\hline & Negative & -0.082 \\
\hline \multicolumn{2}{|l|}{ Test Statistic } & 0.082 \\
\hline \multicolumn{2}{|l|}{ Asymp. Sig. (2-tailed) } & $200^{c, d}$ \\
\hline \multicolumn{3}{|c|}{ a. Test distribution is Normal. } \\
\hline \multicolumn{3}{|l|}{ b. Calculated from data. } \\
\hline \multicolumn{3}{|c|}{ c. Lilliefors Significance Correction. } \\
\hline d. $\mathrm{Tl}$ & & \\
\hline
\end{tabular}

Source: Results of SPSS v.25 Data Processing.

Based on the calculation results in the table above, theresults are obtained Asymp. Sig. (2-tailed) of 0.200 which can be said to be thevalue Asymp. Sig. (2-tailed) 0.200 greater than 0.05 , it can be said that the data is normally distributed. 
Figure 1.1 Histogram Curve

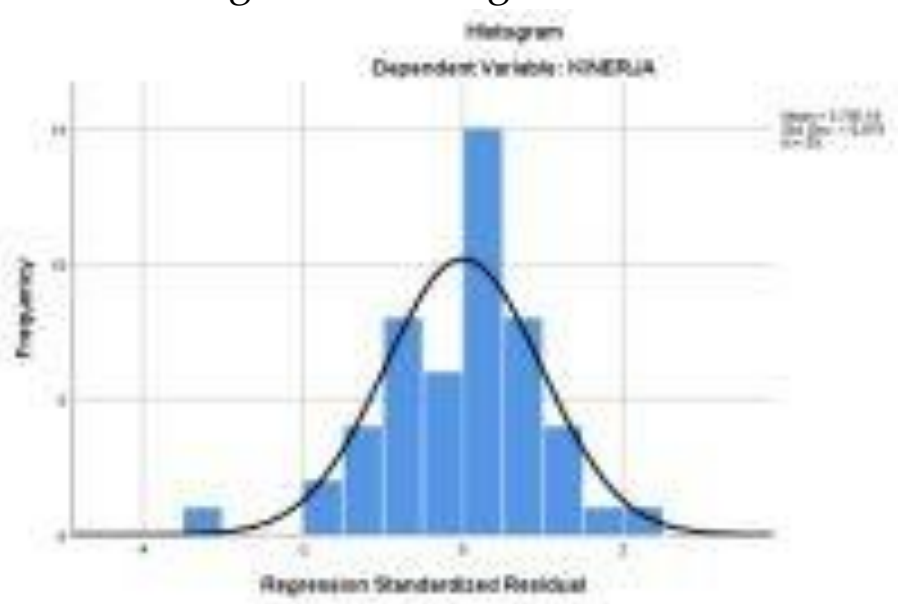

Figure 1.2

Normal Probability Plot (P-Plot)

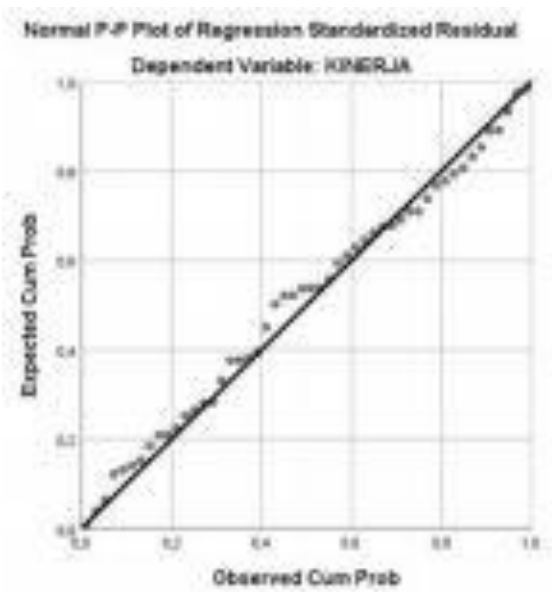

Multiple Regression Analysis

Table 1.8

Multiple Regression Test Results

\begin{tabular}{|c|c|c|c|c|c|c|}
\hline \multicolumn{7}{|c|}{ Coefficientsa } \\
\hline \multirow{2}{*}{\multicolumn{2}{|c|}{ Model }} & \multicolumn{2}{|c|}{ Unstandardized Coefficients } & \multirow{2}{*}{$\begin{array}{c}\begin{array}{c}\text { Standardiz } \\
\text { ed } \\
\text { Coefficient } \\
\text { s }\end{array} \\
\text { Beta }\end{array}$} & \multirow{2}{*}{$t$} & \multirow{2}{*}{ Sig. } \\
\hline & & B & $\begin{array}{l}\text { Std. } \\
\text { Erro } \\
\mathrm{r}\end{array}$ & & & \\
\hline \multirow[t]{3}{*}{1} & (Constant) & 6.542 & 2.420 & & 2.703 & 0.010 \\
\hline & $\begin{array}{l}\text { EXPERIENCE } \\
\text { WORK } 4.005\end{array}$ & 0.457 & 0.114 & 0.498 & $(\mathrm{X} 1)$ & 0.000 \\
\hline & $\begin{array}{l}\text { ABILITY TO } \\
\text { WORK } 0.360\end{array}$ & $(\mathrm{X} 2)$ & 0.142 & 0.315 & 2.533 & 0.015 \\
\hline
\end{tabular}


PRIMANOMICS : JURNAL EKONOMI DAN BISNIS - VOL. 19. NO. 1 (2021)

Versi Online Tersedia di : https://jurnal.ubd.ac.id/index.php/ds

| 1412-632X (Cetak) | 2614-6789 (Online) |

a. Dependent Variable: KINERJA (Y)

Source: SPSS V.25.0 Data Processing Results

From the results of the analysis above it can be seen that the multiple linear regression model is: $\mathrm{Y}=\mathrm{a}+$ $+\mathrm{e}$

$\mathrm{Y}=6,542+0,457 \mathrm{X}_{1}+0,360 \mathrm{X}_{2}+2,420$

Analysis of the Coefficient of Determination

Table 1.9

Test Results of theDetermination Coefficient

\begin{tabular}{|l|c|c|c|c|}
\hline \multicolumn{5}{|c|}{ ModelSummary } \\
\hline Model & R & R Square & $\begin{array}{c}\text { Adjusted } \\
\text { R Square }\end{array}$ & $\begin{array}{c}\text { Std. } \\
\text { Error } \\
\text { of the } \\
\text { Estimate }\end{array}$ \\
\hline 1 &, $731^{\text {a }}$ & 0.535 & 0.515 & 2.01027 \\
\hline $\begin{array}{l}\text { a. Predictors: (Constant), WORKING ABILITY (X2), WORKING } \\
\text { EXPERIENCE (X1) }\end{array}$
\end{tabular}

Source: SPSS V.25.0 Data Processing Results

Based on the table above, the correlation coefficient value between work experience $\left(\mathrm{X}_{1}\right)$ and work ability $\left(\mathrm{X}_{2}\right)$ and employee performance $(\mathrm{Y})$ simultaneously is 0.535 . Furthermore, the calculation of the coefficient of determination is used as follows:

$$
\begin{aligned}
& \mathrm{Kd}=2 \times 100 \% \\
& =0.535 \times 100 \% \\
& =53.5 \%
\end{aligned}
$$

Thus it can be argued that the contribution of the influence between work experience $\left(X_{1}\right)$ and work ability $\left(X_{2}\right)$ on performance amounted to $53.5 \%$, while the remaining $46.5 \%$ was influenced by other factors not examined by the authors.

Hypothesis Testing

T test (Partial)

\begin{tabular}{|c|c|c|c|c|c|}
\hline \multicolumn{6}{|c|}{ Coefficients ${ }^{a}$} \\
\hline \multirow[t]{2}{*}{ Model } & \multicolumn{2}{|c|}{$\begin{array}{l}\text { Unstandardized } \\
\text { Coefficients }\end{array}$} & $\begin{array}{c}\text { Standardized } \\
\text { Coefficients }\end{array}$ & $\mathrm{t}$ & Sig. \\
\hline & B & $\begin{array}{l}\text { Std. } \\
\text { Error }\end{array}$ & Beta & & \\
\hline \begin{tabular}{l|l}
1 & (Constant) \\
\end{tabular} & 6,542 & 2,420 & & 2,703 & 0,010 \\
\hline
\end{tabular}

Table 1.10

T Test 


\begin{tabular}{|l|r|r|r|r|l|}
\hline $\begin{array}{l}\text { EXPERIENCE } \\
\text { WORK 4.005 }\end{array}$ & 0.457 & 0.114 & 0.498 & $(\mathrm{X} 1)$ & 0.000 \\
\hline $\begin{array}{l}\text { CAPABILITY } \\
\text { WORK 0.360 }\end{array}$ & $(\mathrm{X} 2)$ & 0.142 & 0.315 & 2.533 & 0.015 \\
\hline
\end{tabular}

Source: Results of SPSS V.25.0 Data Processing

a. Hypothesis Test (T Test) Work Experience

Based on thetable coefficients above, the $t$ value is $4.005>2.01174$, the $t$ table and the significance value is $0.000<0.05$. So it can be concluded that Ho is rejected and Ha is accepted, which means that there is a positive and significant influence between work experience $\left(\mathrm{X}_{1}\right)$ on employee performance $(\mathrm{Y})$, thus if the value of work experience increases, then the performance will also increase.

b. Hypothesis Test of Job Ability

Based on thetable coefficients above, the $t$ value is $2.533>2.01174$, the $t$ table and the significance value is $0.015<0.05$. So it can be concluded that Ho is rejected and Ha is accepted, which means that there is a positive and significant influence between work ability $(\mathrm{X} 2)$ on employee performance $(\mathrm{Y})$, thus if the value of work experience increases, then the performance will also increase.

F Test (Simultaneous)

Table 1.11

FTest

\begin{tabular}{|l|l|r|r|r|r|c|}
\hline \multicolumn{7}{|c|}{ ANOVA $^{\text {a }}$} \\
\hline \multicolumn{2}{|c|}{ Model } & Sum of Squares & Df & $\begin{array}{c}\text { Mean } \\
\text { Square }\end{array}$ & F & Sig. \\
\hline \multirow{2}{*}{1} & Regression & 218.563 & 2 & 109.282 & 27.042 & $000^{\text {b }}$ \\
\cline { 2 - 7 } & Residual & 189.937 & 47 & 4.041 & & \\
\cline { 2 - 7 } & Total & 408.500 & 49 & & & \\
\hline \multicolumn{2}{|l|}{ a. Dependent Variable: KINERJA (Y) } \\
\hline \multicolumn{2}{|l|}{ b. Predictors: (Constant), WORKING ABILITY (X2), WORKING EXPERIENCE (X1) } \\
\hline
\end{tabular}

Source: The results of SPSS V.25.0 data processing

Based on the table of the results of the statistical calculation of the $\mathrm{F}$ test above or the ANOVA test, it shows that the calculated $F$ value $>F$ table is $27.042>3.20$, and the 
significance value $<0.005$ is $0.000<0.05$, it can be concluded that Ho is rejected and Ha is accepted, meaning that work experience $\left(X_{1}\right)$ and work ability $\left(X_{2}\right)$ together have a positive and significant effect on employee performance $(Y)$, thus if the value of work experience and work ability increases by 1 , then employee performance will increase. amounted to $27.042 \%$.

\section{Conclusion}

1. Work experience has a positive and significant effect on the employee performance of PT Berlian Palugada Perkasa. Thus when work experience increases, employee performance will also increase.

2. Work ability has a positive and significant effect on the employee performance of PT Berlian Palugada Perkasa. Thus when work ability increases, employee performance will also increase.

3. There is a positive and significant influence between work experience $\left(X_{1}\right)$ and work ability $\left(\mathrm{X}_{2}\right)$ together on the employee performance $(\mathrm{Y})$ of PT Berlian Palugada Perkasa. Thus work experience and work ability increase together, then employee performance will also increase.

\section{Suggestion}

1. In work experience, it is suggested that PT Berlian Palugada Perkasa should be further improved, especially in terms of understanding and mastery of jobs that are still low, employees' knowledge of their jobs is still low and employees whose work periods are still lacking. Where employees still need guidance and instructions to better understand the work they are doing.

2. Work ability, it is recommended for PT Berlian Palugada Perkasa, that is, it is hoped that in the recruitment process the training that has been attended is reconsidered whether the training that has been attended is in accordance with the scope of the field of work to be carried out or not.

3. Employee performance, it is recommended that PT Berlian Palugada Perkasa employees need to improve their performance, especially in terms of producing work in accordance with the quality requirements determined by the company.

\section{REFERENCE}

Get up, Wilson. 2012. Human Resource Management. Bandung: Erlangga.

Ghozali, Imam. 2018.Multivariate Analysis Application with the IBM SPSS 23 Program. Issue Eight. Semarang: Diponegoro University Publishing Agency.

Ghozali, Imam. "The Influence of Work Motivation, Job Satisfaction and Job Ability on Pegawi Performance at the Office of the Ministry of Religion, Banjar Regency." Scientific Journal of Business Economics. 3.1 (2017): 130-137.

Cashmere. 2016. Human Resource Management (Theory and Practice). Second printing. Jakarta: PT Raja Grapindo.

Pua, Baverly M. O, Victor PK Lengkong, Djemly Woran. "The Effect of Work Experience and Work Placement on Employee Performance at PT AIR MANADO." Emba Journal. 5.2 (2017): 2761-2770.

Sugiyono. 2019. Quantitative, Qualitative, and $R \mathcal{E} D$ Research Methods. Second Edition. 1st printing. Bandung: Alfabeta. 
Robbins, Stephen P and Timothy A Judge. 2017. Organizational Behavior. Edition 16. Jakarta: Four Salemba.

Hero. 2012. Evaluation of Human Resources Performance: Application Theory and Research. Jakarta: Four Salemba. 